\title{
MUSiCAL RESPONSES TO SEPTEMBER 11TH: FROM CONSERVATIVE PATRIOTISM TO RADICALISM
}

\author{
Martin Cloonan
}

\section{Introduction}

I want to propose something very simple in this paper: that the attacks which took place on 11 September 2001 were attacks on the very idea of America. This is not a new idea. It was cited by the New York Times soon after the attack and subsequently by the cultural critic Greil Marcus (2002). But what I want to add is that as time went on it became clear that the musical responses which were made were defences of America. However, there were not uniform responses, but diverse ones and that is partly because the idea of America is not settled, but is open to contestation.

So what I want to do in the rest of this paper is to first examine notion that the attacks on 11 September were an attack on the idea of America, look briefly at the importance of identity within popular music, chart initial musical reactions to the events and then look at longer term reactions.

\section{An attack on the idea of America}

The attacks on 11 September were strategically chosen to hit the symbols of America as well as the reality of it. The Twin Towers symbolised American economic power, the Pentagon its military might. This was an attack on the psyche of America as well as its buildings and people. Both the targets were attacked for propaganda purposes as much as military ones. What more devastating way could have been found to show rejection of America and all it stands for?

But the point I want to note here is that America itself is a contested notion. For some America is the land of the free, for others it is the Great Satan. Moreover, within America itself the discourse of America is con- 
stantly played out and debated. There are competing notions of what America is. In music one can think of Woody Guthrie's »This Land Is Your Land « which claims America for its people (rather than just some of them) and compare it to that of »God Bless America «y Irving Berlin which is much more about praising America as it is.

It is therefore not surprising that debates about what it is to be American and how therefore one should respond to attacks on the very idea of America get played out within one America's greatest cultural gifts to the world - contemporary popular music. Within that art form notions of identification have played a very important role.

\section{Identity in popular music and national identity}

One commentator who has noted the importance of identity in popular music is Simon Frith who has argued that:

»The experience of pop music is an experience of identity: in responding to a song, we are drawn, haphazardly, into emotional alliances with the performers and with the performers' other fans « (Frith 1996: 123).

He also says:

»The first reason [...] we enjoy popular music is because of its use in answering questions of identity: we use pop songs to create for ourselves a particular sort of self-definition - a particular place in society. The pleasure that pop music produces is a pleasure of identification - with the music we like, with the performers of that music, with other people who like it« (Frith 1987: 140).

Thus for Frith processes of identification are the very heart of the popular music process. Thus in terms of $9 / 11$, we have an art form which is intrinsically wrapped up in personal and collective identity and which is historically located within a country which found its underpinning ideals under attack. Under such circumstances, it seems to me that two things were bound to happen. First, popular music was going to respond to the events of 11 September and, second, those responses were bound to be diverse and to produce further reactions including controversy and the arousing of all sorts of emotions.

I will return to this soon, but first I want to say something about national identity. Here it is important to note that any national identity is a construct. It is part of what Benedict Anderson (1991) has called an »imagined community«. In his classic text, Imagined Communities, Anderson makes a simple, but important, observation, which is that nations, and in- 
deed all communities, are imagined. We can never, or at least rarely, point to moments when communities and nations are all gathered together. Therefore we have to imagine them in our heads.

This means that national identities have to be made and, importantly, remade. Notions of national identity don't exist set in stone, they are the subject of debate, construction and re-construction. In other words national identity is a site of contestation. There are different, competing, versions of any nation and music is one of the sites where the competing visions are played out. This is at least as true of the United States as it is anywhere else, and perhaps more so.

As I have noted elsewhere (Cloonan 1997) competing views of national identity were played out within popular music in the 1990s and they continue to be debated and fought over. So it is no surprise that when musical responses come to 11 September, they are bound up with debates not only about what a suitable response should be, but also what a suitable American response should be and what America stands for. These issues take some time to play out, but I now want to look at more immediate responses.

\section{Initial reactions}

I want to suggest that three things happened almost immediately after $9 / 11$. First, there is the feeling that music is of no consequence after such appalling events. Second, there are feelings that particular forms of music or songs are singularly inappropriate responses and this leads to censorship. Thirdly, the music industry rallies round in a way which it often does via the staging of fundraising gigs.

\section{The day the music died?}

As has been noted elsewhere (Zalot 2002: 31), many people publicly expressed the fact that they did not want to hear any music in the immediate aftermath of 9/11. Thus the NMEs New York correspondent commented to its British readers that: »It seems trivial to talk about music right now « (NME, 22 September 2001: 4), while another said: »My job is to write about hip-hop and fashion and I couldn't imagine anything more redundant « (ibid.). The magazine itself headlined with »Music Industry Halted by US Tragedy« (ibid.: 6) and reported on various gigs and tours which had been cancelled or postponed in the light of the events. 
While it became clear that people soon returned to music, often in attempts to come to terms with the events, another early response was to raise questions about the extent to which the events had changed music itself. So in the following week the NME asked "Can music ever be the same again « (Beaumont 2001: 18) and concluded that »it's definitely rock'n'roll changing forever (ibid.). Across the Atlantic the US DJ Donielle Flynn asked: »After the extreme tragedy and loss that has touched us all, how can music possibly sound the same?«(Zalot 2002: 34).

To some extent these responses on both sides of the Atlantic can be seen as media hyperbole, but even in academic circles, it was speculated that things had changed forever. For example, the American academic Murray Forman (2002: 192) argued that »music has acquired a new significance in relation to the atrocities of the terrorist actions «.

I want to suggest that this is, at best, only partly true and that in the main music carried on many of its traditional roles. As Forman himself notes, music was soon "employed spontaneously in countless healings and public vigils and public demonstrations and in highly organized media megaevents« (ibid.: 191).

I want further to suggest that one of the key roles which it continued to play was that of shaping and informing national identities. The key thing which changed here was the politics around such formulations. As we shall see, post $9 / 11$ it became increasingly hard for musicians to express dissent, not because music had lost its power to be able to do this, but because of a changed political climate.

To summarise, many initial reactions portrayed music as useless after $9 / 11$, but soon it was being used in all sorts of ways. This is a reflection of the power of music and that power is also reflected in another initial reaction - that of censorship.

\section{Censorship}

Perhaps the most widely publicised case of censorship was that of the list of 156 records which were allegedly banned by Clear Channel from their 1,170 radio stations. This list was apparently drawn up by an over zealous employee but was widely reported as a management-sanctioned ban. It included a list of possibly offensive or insensitive songs and included all songs by Rage Against The Machine (Beaumont 2001: 20). Rage Against The Machine's website was also closed by its ISP after what were described as »numerous calls from the Secret Services complaining about the antiAmerican sentiments expressed there (ibid.: 3). Clear Channel's list also 
included Lennon's »Imagine « which, as we shall see, came to a somewhat eventful life in this story. ${ }^{1}$ The list circulated in various forms around a number of stations, but it was neither an executive memo nor an attempt to ban songs. Eric Nuzum explains that:

»The lists were compiled by a senior vice president of programming at Clear Channel, and then e-mailed from corporate management to the more than 1,100 individual channels under Clear Channel's ownership. While the management e-mail did not call for an overt ban on songs, it did ask that programmers use >restraint $<$ when selecting songs for airplay« (Nuzum 2002: 2).

The story appeared on music industry websites on 14 September and in the mainstream press on the 17th. Clear Channel then issued a statement which said that it had not banned any songs, although it did not deny the existence of the list nor any censorious acts by its employees. It argued that radio is a local medium and so local music selectors could exercise their judgement. It concluded. It also highlighted its American credentials by saying:

»Clear Channel strongly believes in the First Amendment and freedom of speech. We value and support the artist community. And we support radio station programming staff and management teams in their responsibility to respond to their local markets« (ibid.: 8).

Whether or not the list was a ban, it soon attracted the ire of anti-censorship campaigners. Thus Nina Crowley of the Massachusetts Music Industry Coalition said:

»It's very dangerous... I understand they're pulling certain violent songs. But you put out a list of songs like this and the next thing you know is somebody is pulling the albums off the shelves in Wal-Mart « (Nina Crowley, cited in Beaumont 2001: 20).

\section{Eric Nuzum argues that:}

»While Clear Channel is quick to point out there was no explicit censorship involved with the list, it is a perfect example of music censorship at its most

1 The lists of songs on the Clear Channel list can be found in Nuzum (2002), on www.massmic.com and on p. 60f. in this book. Most of songs have references to burning, death and plains, but also it also included Cat Stevens' »Peace Train«, Lennon's "Imagine « and all RATM songs. Nuzum (2002: 3) comments: 'What do these songs have to do with flying airplanes into buildings? Absolutely nothing. Yet in the past each of these artists has expressed controversial political statements that buck mainstream beliefs . He also notes that some songs showed a troubling degree of literalism and prejudice in compilers, citing Peter and Gordon's »| Go To Pieces « as an example. The list is also redolent of a similar list compiled within the BBC during the 1991 Gulf War (see Cloonan 1996: 118-120). 
implicit. Regardless of Clear Channel's intentions, censorship did occur « (Nuzum 2002: 2, emphasis in original).

He continues that while some Clear Channel programmers said that they did not follow the list, many more said that they did and removed all the listed songs from broadcast and/or exercised restraint. He concludes that:

»The list's existence and resulting actions are a perfect example of how a wellintentioned attempt at ssensitivity< can quickly career down the slippery slope towards stifled free expression« (ibid.: 3).

From a contrary point of view, Michael C. Zalot (2002: 39) argues that it is not clear that the list had any effect and he has evidence that many Clear Channel DJs simply ignored it and played what listeners requested, including songs from the list. However, the Mass M.I.C. website has evidence that at least one station took the list seriously and did not play any material on it (www.massmic.com).

Zalot (2000: 40) also notes that what is frustrating about such lists is that they often contain exactly the sorts of songs that many listeners would want to use to help them, cope with the tragedy. Nuzum (2002: 4) astutely notes that many Americans saw defending music as comparatively trivial at a time of national emergency, but that is exactly when music and other forms of free expression most need defending. For Nuzum (ibid.) music is freedom.

Back in the UK the BBC's Radio 1 was reported as keeping clear of »more upbeat songs in the week following the incident «, but soon getting back to normal (Beaumont 2001: 20). It was also said by a spokesperson to »make sure that the station is in tune with how listeners are feeling (ibid.). In keeping with this mood the BBC's Radio 2 station ensured that it did not play Goldfrapp's »Pilots « and Aerosmith's »Fly Away From Here«. Meanwhile the commercial radio station, Virgin, dropped the Stereophonics' »Have A Nice Day« (NME, 22 September 2001: 6).

Another case of censorship came when the Marxist rap duo, The Coup, had to change the 18 month old planned cover of their Party Music album. This cover featured the Twin Towers in flames and was vetoed by the band's label 75 Ark after electronic copies had been distributed in advance to the media. The group's leader, Boots Riley, said that the cover was a metaphor for the capitalist state being destroyed through music, although he seems to have given differing accounts of what happened to the cover (Nuzum 2002: 5).

The climate of fear also affected classical musicians. The composer John Adams found himself castigated as anti-American in the New York 
Times because his opera "The Death of Klinghoffer « was seen as romanticising Palestinian terrorists of the 1980 s and thus those of $9 / 11$ as well. His main critic, Richard Taruskin of the University of California, said that the opera should not be performed under the existing circumstances and that »What is called for is self control « (Kettle 2001).

The Boston Symphony Orchestra cancelled three planned performances of the opera in November 2001 because, said its Chorus Director John Oliver, it wanted »to err on the side of being sensitive « (ibid.). Adams was angry at the cancellation, accusing the BSO of assuming that audiences want to be comforted when they might want to be challenged by art. He commented that:

"In this country, there is almost no option for the other side, no space for the Palestinian view in a work of art [...] Susan Sontag said recently that she found the mood unprecedented in more than 40 years, and I agree« (ibid.).

There are three points which I want to make about this censorship here. First, censorship of music is part of American history (cf. Martin/Segrave 1988; Nuzum 2001). The second is that if, as argued earlier, a key part of music is the identification process then it is clear that some people's identity was being denied. Third, in contrast to some initial reactions, it shows that music was important immediately post $9 / 11$, if only because some musical responses were deemed as being inappropriate. It should also be noted here that as time passed the overt censorship was replaced by more covert forms when attempts were made to silence dissident voices.

Another manifestation of this climate is the March on Hollywood website (www.marchonhollywood.com) which attacks all the anti-Bush celebrities including Madonna, Michael Stipe, Barbara Streisand and Sheryl Crow. ${ }^{2}$

Thus censorship can initially be seen as an attempt not to upset people, but in the longer term it developed into a more insidious form where those who doubted the wisdom of George Bush's foreign policy were deemed to be the same as the terrorists of $9 / 11$ in that both were anti-American. Instead of attacking the President, say detractors, critics should rally round the President and rallying round is the third initial reaction to $9 / 11$.

2 The site includes attacks on Sheryl Crow for saying that it's better not to have enemies after she had previously played for troops in first Gulf War, George Michael for saying that a Gulf war will ignite Islamic fundamentalism, Moby for attacking George Bush's links with big business and Michael Stipe for saying Americans support inspections - not war. Stipe later commented that: "I feel a backlash against my politics every time I walk a city block« (Ross 2003: 5). The site also attacks Queen Latifah and Madonna and notes the fact that the Dixie Chicks' Natalie Maines is married to Adrian Pasdar - »an American of Iranian descent $\ll$. 


\section{Rallying round}

Another more immediate reaction from the reaction from the music industry was to rally round. There were a range of benefit concerts and related activities soon after the event. These included the telecast show America: $A$ Tribute To Heroes which included contributions from Neil Young, Bruce Springsteen, Stevie Wonder, Celine Dion, Eddie Verder, Mariah Carey and Billy Joel (Helmore 2001). Reports cited Neil Young performing Lennon's "Imagine « as a highlight of the show, which was somewhat ironic given the fact that the song had appeared on Clear Channel's list. In fact the song has enjoyed a chequered history (cf. Negus 1996: 191-196) but post 9/11 it seemed to strike a chord with many Americans and became one of the most requested songs from radio listeners (Beaumont 2001: 20; Zalot 2002: 35). Zalot (2002: 35) argues that this might be because the song calls for a world free of religion and religion was widely seen as being behind the attack.

Another report on the telethon noted that all the material was either cover versions or old songs (Petridis 2001) and included nothing about the events or the people involved in them. Seemingly it was too soon or artistically risky to do that, although Paul McCartney wrote a song called »Freedom« the following day.

Another benefit was The Concert For New York City on 20 October 2003 at Madison Square gardens. It was organised by Miramax Co-Chair, Harvey Weinstein, VH1 cable President John Sykes and James Dolan whose company owns the gardens (Garside 2001; Ellison 2001). The tickets cost up to $£ 6,000$ each (Garside 2001), the concert raised $\$ 14$ million itself, while donations made in the light of it were said to top the $\$ 125$ million raised by the telethon (Ellison 2001). In keeping with the establishment feel of things, the concert featured a number of artists who had also appeared at Live Aid such as U2, David Bowie, Mick Jagger, The Who, Billy Joel, Jon Bon Jovi, Destiny's Child, Macy Gray, Janet Jackson, the Back Street Boys, Elton John and Paul McCartney. ${ }^{3}$ The latter performed in a NY Fire Department t-shirt and played »Freedom « a song which, as noted above, was written on 10 September and was described by one commentator as a »eulogy to American democracy«. The lyrics include:

»This is a right given by God. We're talking about freedom and I will fight for the right to live in freedom. And anyone who wants to take it away will have to answer. Because this is my right« (Garside 2001).

3 The role of non-Americans in helping to forge an American response to $9 / 11$ is noteworthy here. 
A more left-field benefit was organised by the Beastie Boys under the heading New Yorkers Against Violence which was meant to support all those affected by $9 / 11$ and to promote peace in the Middle East and Tibet (Long 2001). Artists who made surprise appearances included Bono, Michael Stipe and Moby.

The corporate nature of these events should be noted, as Forman (2002: 203) does when he suggests that the ultimate criterion for judging the success or otherwise of these events is how much money they raise. The telethon and Concert For New York City are now both available on CD and DVD. There is also a range of CDs which aim to raise money for 9/11 victims. There were essentially two responses from the industry here. One was the compilation of new CDs with "patriotic « music on them, the other the promotion of existing CDs as particularly relevant under the circumstances:

Examples of the former include the America: A Tribute To Heroes CD featuring Bruce Springsteen and the Dixie Chicks who were both to become embroiled in post 9/11 politics. There were also the Love Songs For New York: Wish You Were Here collection, Daniel Rodriguez's The Spirit Of America, Denyce Graves and others' American Anthem and the Mormon Tabernacle Choir's The Majesty Of America.

Another compilation was also Columbia Record's God Bless America: A Collection Of Songs of Hope, Freedom \& Inspiration CD on which the promotional blurb says »Columbia Records rushed this compilation of patriotic and inspirational favourites into production in the wake of the September 11, 2001 attacks « and that: "A substantial portion of the proceeds received by Sony Music from the sale of this album will be donated to The Twin Towers Fund. The fund aids the families of Police, Fire, EMS and other City employees involved in rescue efforts surrounding the events of September 11, $2001 \ll$.

The artists on this album include Celine Dion, Bruce Springsteen, Mariah Carey, Tramine Hawkins, Bob Dylan, Simon and Garfunkel, John Mellencamp, Billy Gilman, Frank Sinatra, Lee Greenwood, Pete Seeger, Gloria Estefan, Mahalia Jackson, The Mormon Tabernacle Choir and Bill Withers. The title track is Celine Dion's version of the Irving Berlin song which she did on the Tribute To Heroes telethon. One thing to note here is that the album includes protest music from Seeger, Dylan and Mahalia Jackson which were now removed from their original context and used in a project to reunite the nation. Here forms of music which had been used to critique the status quo were utilised in order to try and rebuild the same status quo. ${ }^{4}$

4 See www.11-sept.org/music.html for three pages of "patriotic « CDs. 
It was noted that these events involved people from across the whole of the music industry (Forman 2002: 195). It was a corporate response and, argues Murray Forman, it proved Attali's point that today "where there is music, there is money« (Attali 1985: 4). As corporate America had been attacked, so the response was corporate. Forman argues that

»the television and recording industries are already packing the post-attack events as historical commodities that will compete with other cultural products on the market. In their presentation and packaging, they also offer immeasurably promotional opportunities for the artists involved (Forman 2002: 196-197).

Or as the NME cynically put it soon after $9 / 11$ :

»The millionaire superstars [will soon] lay in with charity records which will re-establish their careers for at least half a decade to come« (Beaumont 2001: 2).

Once again this should not surprise us. Reebee Garofalo (1992) has also showed this with Live Aid, an event upon which Will Straw commented that »the most under-rated contribution rock musicians can make to politics is their money, or way in which money can be raised « (Forman 2002: 197). Thus even the most aware artists, such as Bono and Springsteen, are most often seen active in fundraisers. However, this can not be spelled out. So Forman explains that:

»The most frequently deployed discourses in the plethora of post-September 11 relief concerts involves $d u t y$, the essence of which is to join the effort to generate money and financial resources. In the current crisis, however, it is difficult to disentangle the discourse of duty from the political and ideological articulations woven into the project of nation building (Forman 2002: 197, emphasis in original).

In other words, the charity of musicians was utilised not only for the physical reconstruction of the United States, but also its psychological and ideological reconstruction. Examples of this were not hard to find. Michael Jackson gathered an array of stars to appear on his recording of »What More Can I Give« for 9/11 victims (ibid.: 196). Britney Spears was said to be donating \$2 million from her tour (NME, September 2001: 3) and Dr Dre \$1 million (NME, 6 October 2001: 4). Nsync were amongst the artists who recorded a new version of "We Are Family « to raise cash (ibid.). A planned AIDS charity single version of »What's Going On« featuring Fred Durst of Limp Bizkit had half of its proceeds diverted to the 11 September fund (NME, 20 October 2001: 4). 
Thus many within the industry rallied round, but meanwhile others found that popular music fans were calling upon them to use music as part of the healing process. While high profile concerts were a high profile way of rallying round, then the use of music on radio was a more discrete, but possibly more influential way. Forman (2002: 194) notes that after 9/11 Rolling Stone reported that listener phone-ins reflected the desire to harness music for a public forum of clashing sensations. So there were any requests for Johnny Cash's »Ragged Old Flag « and Brooks and Dunn's »Only In America «, while on classic stations »Imagine « and »Bridge Over Troubled Water « were heavily requested. Many stations received requests for the "Star Spangled Banner« especially Whitney Houston's version which was performed live at the Superbowl during the first Gulf War and which went back into the Top 10 of the charts. Rock stations played the Hendrix version, the anger of which was now used to promote nationalism. On television, MTV tried to provide peaceful backdrop with »Imagine «, Bob Marley's »One Love «, Prince's »When Doves Cry«, U2 and Pearl Jam's »Alive«.

Almost all radio stations got requests for Lee Greenwood's "God Bless The USA«. Zalot (2002: 39) argues that »Rock stations simply had nothing analogous to Greenwood's song. Rock music's historically anti-establishment rhetoric precluded such a nationalist expression, especially without the use of irony or irreverence «. In the longer term country seemed to enter the void to claim that it was the most suitable response (Sutherland 2002). More generally Forman comments that:

»The conscription of music can be approached through what Middleton [...] identified as a theory of articulative process whereby music and musical meanings are rechannelled in a manner that reproduces the hegemonic structure and, pace Gramsci, reaffirms the prevailing social order of domination and subordination« (Forman 2002: 194).

In other words: music was used here to help people cope, but also to return them to normality and comfort them (ibid.; Zalot 2002: 32). What that normality consists of is a society which is based on economic imperialism and domestic racial and class divides. In the longer term the imperialist response was seen in Iraq, while in the shorter term music was used to unite the nation in ways which temporarily supplanted class and racial antagonisms. In the longer term those antagonisms were bound to return as the very idea of America became open to contestation again. In the short term 
grief and anger made that impossible and music was used as a form of social glue. $^{5}$

In an interesting article which includes interviews with radio station personnel about their responses to 9/11, Michael C. Zalot (2002: 27) argues that responses to the events from a radio viewpoint can be seen at three levels - individual, communal and institutional. Music radio can serve a number of functions in times of crisis including gathering information, social integration and allowing a release of tension (ibid.). In the latter case radio stations can respond with their own formats or they can respond to listeners' requests. Zalot notes that in the immediate aftermath radio stations had to rely on existing materials, but that later a number of them started to mix their own materials - by such things as interjecting news reports into old songs (ibid.: 41). He suggests that:

»In the wake of September 11, listeners turned to local rock, pop and country stations for a sense of community, in a virtual public space that television did not provide« (Zalot 2002: 34).

Thus despite the high prominence of the televised events, it seemed to be radio which best articulated the feelings of music fans. In general fans were more able to make instant responses, but I now want to look at more long term musical responses.

\section{Later reactions}

I want to suggest that the longer term musical responses to 11 September can be divided into three groups. The first of these is the conservative patriotic, the second is the liberal patriotic and the third is the radical and I'll deal with each in turn.

5 Radio responses were genre bound and some requests were denied. Thus Zalot (2002: 36) reports that S.OD.'s »Fuck The Middle East« was requested at WYSP, but not played. Forman (2002: 199) also notes that despite their huge popularity rap and metal were absent from television events around $9 / 11$, presumably as they were deemed to be inappropriate and not mainstream enough. »It is essential to maintain a critical awareness of which songs and genres are deemed most appropriate under the circumstances and, by extension, which are largely excused from public debate and excluded in the processes of defining appropriate public sentiment« (Forman 2002: 191). 


\section{The conservative patriotic response}

The conservative patriotic response can be seen as one which has a comparatively narrow view of the Constitution and which is founded on feelings of xenophobia. Within the conservative patriotic response there is no attempt to understand the enemy, simply to crush it. In part we can see this in many corporate responses to the events both in terms of songs and marketing methodologies where the US flag featured prominently. The flag was also the inspiration for what became perhaps the most well known conservative response to $9 / 11$, Toby Keith's "Courtesy Of The Red, White and Blue (The Angry American)«. This country and western song celebrated the American bombing of Afghanistan with the lines »Man we lit up your sky « and the words

»Oh, justice will be served / And the battle will rage / This dog will bite you if you rattle his cage / You'll be sorry that you messed with the US of A / Cause we'll put a boot in your ass / It's the American way" (Campbell 2002).

Of course, it was exactly what constituted the American way and how that way should respond to the events of 9/11 which was debated. Keith's conservative patriotism enraged American liberals and his planned appearance on ABC's 4th July celebration show in 2002 was pulled after its presenter Paul Jennings objected to the song. The line about a boot in the ass outraged Jennings, yet earned Keith applause at concerts. Keith responded by dedicating the song to Jennings and making remarks about him being Canadian. It was reported that George Bush had invited Keith to appear to play "Star Spangled Banner « at White House (Sutherland 2002).

Meanwhile the battle to stifle any political dissent began. The actor Tim Robbins reported in April 2003 that:

"A famous middle-aged rock'n'roller called me last week to thank me for speaking out, only to tell me he could not speak himself because he fears repercussions from Clear Channel [...] A chill wind is blowing in this nation. A message is being sent through the White House and its allies in talk radio and Clear Channel. If you oppose this administration, there can and will be ramifications. Every day the airwaves are filled with warnings, veiled and unveiled threats, invective and hatred directed at any voice of dissent."

He concluded that:

»We need leaders who can understand the constitution [...] our ability to disagree, and our inherent right to question our leaders and criticise their actions, define who we are. To allow those rights to be taken away out of fear, 
to punish people for their beliefs, to limit access in the media to differing opinions, is to acknowledge our democracy's defeat« (Robbins 2003).

This echoed a persistent theme in the aftermath of $9 / 11$, the debate about what it means to be American. Whether it involved blind deference or critique; revenge or attempts to understand. For the conservative patriots the role of musicians was to support, not to critique, to comfort, not to confront. Those who strayed into critique found themselves vehemently attacked.

Perhaps the most obvious example of this was the attacks which were made on the Dixie Chicks following lead singer Natalie Maines saying at a London gig that "We're ashamed that the president of the United States is from Texas «. This remark was picked up by country and western websites and resulted in the band being called such things as "Saddam Angels", »Dixie Sluts«, traitors etc. Country radio stations stopped playing their new album, »Home« and »invited listeners to dump their old albums in rubbish bins and there have been death threats and calls to boycott their upcoming US tour « (Campbell 2003). Toby Keith used a backdrop of Maines and Saddam Hussein depicted as lovers at his concerts (ibid.).

Clear Channel allegedly banned them from all its radio stations »out of respect for our troops and our listeners« (Williamson 2003: 7). In one Louisiana town a steamroller was used to crush Dixie Chicks' CDs. In Little Rock, Arkansas, a local radio stations handed out anti-Dixie Chicks t-shirts and the Red Cross turned down a donation of $\$ 1$ million from the profits of the tour because President Bush is one of its patrons (ibid.). Ironically the band had previously sung at that definitely American event, the superbowl and appeared on the America: A Tribute To Heroes CD.

Maines apologised and said that whoever is President should be treated with utmost respect. She was also given a 24 hour bodyguard. However, she noted that the US ambassador to the UK had obviously had no problems with her comments as he had visited the band backstage after the show in question (Campbell 2003). She later seemed to harden her views and vowed to continue speaking out, finding support from both Bruce Springsteen and Dolly Parton amongst others.

Overall the overtly conservative patriotic musical response has been rather limited and artists such as Toby Keith can be seen at one level as merely being populist bandwagon jumpers. But they do seem to have captured a certain mood which is abroad in the US, which seeks to represent any dissent from policy as an example of disloyalty. This has in turn fed the zeal of those who damn the Dixie Chicks and want to march on Hollywood. For these conservative patriots to be an American is to follow the President. 
But this view is not universally shared and this idea leads me into discussing the second type of musical response, the liberal reflective.

\section{Liberal patriotism}

The liberal patriotic response covers a wide area from Bruce Springsteen through the Dixie Chicks to Steve Earle. ${ }^{6}$ The musical responses range from sorrow about $9 / 11$ through reflection about why the events occurred up to a very liberal interpretation of the Constitution, especially as it relates to freedom of speech.

One of the most high profile performers to continually address $9 / 11$ is Bruce Springsteen. He appeared on both the America: A Tribute To Heroes CD (and telethon) and the God Bless America CD. Discussion of the meaning of Springsteen's actions are complicated by the fact that he has often been appropriated by the political right, while espousing liberal causes and donating money to strike funds etc. The most famous example of this is when his »Born In The USA « was used by Ronald Reagan in election campaigns as a patriotic anthem, when its author intended it as lament for the fate of Vietnam Vets.

In fact Springsteen is an artist whose work has constantly referred to the plight of America or, more precisely, of its working men. As a native of New Jersey, it was not surprising that Springsteen would get involved in raising money for the victims of 9/11 nor that he should address it in his work. He does this on the 2002 album, The Rising. Eight of the 15 songs on the album are laments for lovers who died in the attacks.

But at least one commentator thought that the task presented to Springsteen was too much for him. Thus in the Guardian Alexis Petridis wrote that:

„Springsteen's limited metaphorical palette has been noted before - he spent 15 years writing songs in which unemployed Vietnam vets called Gary tried and failed to escape their destiny by driving down the highway - but here the repetitions are highlighted by their proximity. A song in which the streets are cloudy with dust and flowing with blood, and the sky is empty and crying, is followed by a song in which the sky is cloudy with dust and raining blood, and the streets are empty and crying " (Petridis 2002).

This is perhaps a little unfair, but it does show some of the issues facing artists who try to address $9 / 11$. The enormity of the events can dwarf at-

6 Ironically both Earle and the Dixie Chicks share a country and western heritage with Toby Keith. 
tempts to capture them in song. Springsteen attempted a thoughtful and sorrowful response. He was never likely to go in for the crass patriotism of Toby Keith, but neither could he point the finger at America. Instead he commented on the sadness. This was liberal patriotism which cared for the victim, but did not call for revenge (although one of the characters in the song »Empty Sky« says he wants an eye for an eye), nor try to understand the motivations of the perpetrators - although »Worlds Apart « does contain some Arabic sounding backing music. Moreover the album also contains upbeat party songs such as »Mary's Place « and "Waiting On A Sunny Day« which sit uneasily amongst the more sorrowful material. In addition the album re-unites Springsteen with the E Street Band, whose playing often verges on the bombastic. To this listener, Springsteen might have been better placed to have recorded his material alone.

Meanwhile it was when a leading liberal tried to understand the perpetrators that real controversy was provoked and perhaps the most controversial response was that of Steve Earle who wrote a song called »John Walker Blues «, from his 2002 album Jerusalem. The song is about the »American Taliban « John Walker Lindh, who joined the Taliban and was captured by the Americans fighting in Afghanistan. He was subsequently sentenced to 20 years in prison (Nuzum 2002: 2).

Earle explained that he became interested in Walker because he was the same age as his son and had become totally alienated from the society into which he was born. He was also intrigued that Walker had come to Islam via hip hop. The song portrays Walker as an ordinary US boy - »raised on MTV « - who becomes alienated from a society which seems to make no sense to him and so becomes a radical Muslim. Attempts to censor the song began two months before it was even released (ibid.). Part of the song is written from Walker's point of view. Perhaps the key lines are:

»I'm just an American boy, raised on MTV. [...] And I've seen all those kids in the soda pop ads, and none of 'em looked like me / So I started lookin' around for a light out of the dim / And the first thing I heard that made sense was the word / Of Mohammed, peace be upon him.«

There are also references to Jesus' place in the Koran. The song is a liberal attempt to understand, but not defend Walker. Nevertheless, in post 9/11 USA compassion was at a premium. The Rupert Murdoch-owned New York Post headlined with »Twisted Ballad Honours Tali-Rat« and says Earle has glorified Walker (Davidson 2002) and the Wall Street Journal commented that in this case artistic freedom was a watery line of defence (Wilson 2003). The Nashville radio personality, Steve Gill, a lawyer who once defen- 
ded Earle, believed that Earle was just trying to be outrageous to get attention. Gill argued that the Jesus reference was particularly outrageous and set about organising a boycott of any station which plays the song (Davidson 2002). He also accused Earle of joining Jane Fonda and all the other antiAmericans (Harris 2002). Earle responded by saying that the only thing he couldn't do was not say anything (ibid.).

The sleeve notes to the Jerusalem album make it clear that Earle sees his role as defending the First Amendment of the US constitution which guarantees the right to freedom of speech. ${ }^{7}$ What is important about this statement is that Earle is placing himself in a long line of patriots. His articulating a view of America which is very different to that of the conservative patriots, but which is still very much part of an American tradition. Earle is not seeking to overthrow the American system, rather he wants it to fulfil its potential. For him the traitors are not those who oppose Bush and the calls for revenge, but those who forget this tradition. It is in this sense that I see Earle as a liberal patriot.

For the conservative patriots, America had to be reconstructed as a nation of heroes. In contrast, Al Qaida and the Taliban had to be seen as inhuman. Therefore to suggest, as Steve Earle did, that John Walker was definitely American as well as a Taliban supporter was blasphemy indeed. In the new Bush world order, definitions of what it is to be an American are being reconfigured and within the mainstream they did not include the possibility of supporting the Taliban. Part of any war involved dehumanising the enemy and to humanise Walker in the way Earle did was bound to cause the right to react. The fact that Walker is shown to have Christian as well as Islamic sentiments, merely compounded the insult.

7 On the sleeve notes to Jerusalem Earle writes: »We are a people perpetually balanced on a tightrope stretched between our history and our potential, one faltering step away from a heading tumble from the most dizzying of heights. But fear not - we're wearing a net. / In spite of our worst intentions and ignorance of our own history our Constitution has, thus far, proven resilient enough to withstand anything that we throw at it including ourselves. For myself, my faith in this one institution of our all too human (and therefore imperfect) society is absolute but, I hope, not blind. It was built to last but only if properly maintained. Fierce vigilance against the erosion of its proven principles is the very heart of our peculiarly American brand of democracy. It was framed by men whose names we're taught to remember by rote: Thomas Jefferson, Benjamin Franklin, John Adams, Patrick Henry, Aaron Burr... the list is long and distinguished and we call these men patriots. In times like these it is also important to remember the names of John Reed, Emma Goldman, Abbie Hoffman, Bobby Seale, Malcolm X, Martin Luther King... those who defended those same principles by insisting on asking the hardest questions in our darkest hours. / God bless America, indeed.« 
So, for me Earle does encapsulate a liberal patriotic response to 9/11. His defence of America is not a defence of the country warts and all, but one posited on what it could and should be.

Somewhere between the patriotic liberal response and the radical is the Axis of Justice organisation formed by Tom Morello of Audioslave and Serj Tankian of System of a Down. According to its website its "purpose is to bring together musicians, fans of music, and grassroots political organizations to fight for social justice together « (www.axisofjustice.org). The website does, however, contain links to anarchist and more radical sites and this leads us to the last form of response.

\section{The radical response}

The final response to $9 / 11$ is the radical, which here I equate with revolution and a desire not merely to reform the present American system, but to overthrow it. I don't want to suggest here that the radical musical reaction to $9 / 11$ has been particularly widespread. In fact is has been minimal and at times almost unnoticeable. But this should not surprise us in a country which has never produced a mass socialist movement. The radicals in the US have always been in the minority and this was always likely to be exacerbated by $9 / 11$. But, like the pea under the princess' mattress, they are there causing discomfort and arguing that a complete overthrow of the American system is both desirable and possible. They also have their musical expressions.

Soon after 9/11, one British commentator noted that »rebellion, the lifeblood of rock music for over 40 years, is suddenly off the agenda « (Petridis 2001). But at first some commentators speculated that if a more radical response came from within popular music, then it would come from rap (Beaumont 2001: 20). For example, Murray Forman noted that:

»If the past offers any lessons for the future, then the most detailed, explicit and sustained musical discussions of the September 11 attacks will almost certainly emerge through the lyrics of rap and the images and discourses of the hip-hop culture (Forman 2002: 202).

In fact the response from some rap quarters was decidedly patriotic. The rapper Canibus released a song called »Draft Me« which fully supported the war in Afghanistan and contained the lyrics »Draft me! / I wanna fight for my country / Draft me and murder those monkeys! / Draft me! / I'm too dedicated to fail / Justice must prevail, justice must prevail« (Lynskey 2002: 12). The Wu-Tang Clan put a verse into their album Iron Flag which 
declared: »America, together we stand, divided we fall« (ibid.), while (MC) Hammer posed before the flag and called his comeback album Active Duty.

There are a number of reasons why rap's response was more patriotic than radical. First, rap has always been about commerce as much, if not more, than social commentary. Rappers have perhaps been the most overt consumers of all popular musicians - as shown by the overt use of gold chains etc. In this sense a lot of rap is actually pro-American. It has bought into the sorts of American ideologies which were so firmly rejected by Al Qaida. Thus rap's own values were under attack. It is little wonder therefore that the response from the rap world mirrored that found elsewhere - general support for the war (in Afghanistan) and US patriotism. The overwhelming attitude was summed up by Surge King, head of Death Row Records: »We're supporting the USA. At this moment, there is no such thing as ghetto, middle class or rich. There's only the United States « (Lynskey 2002: 13). In many ways this can be seen as rappers defending their »hood« (ibid.).

The radical Islamic rappers are a minority and they were keeping quiet. Moreover, the sort of Islam which Public Enemy advocate in first world America is somewhat removed from the third world fundamentalism of Al Qaida. Thus for US Islamic rappers Al Qaida were more likely to be viewed as others, rather than brothers.

But there were some more radical reactions, included that of the previously noted Marxist duo The Coup. They call the US flag »violent gang colours « and refuse entry to their gigs to those wearing it (ibid.). Other rappers such as Chuck $D$ and Busta Rhymes were also critical of US foreign policy post 9/11 (Lynskey 2002: 13). In the case of Public Enemy, the rise of Bush seems to have re-energised the band who currently open their show with a song called »Son Of A Bush «.

Another rapper, Cam'ron, and his crew, the Diplomats caused controversy because of the song "I Love You« which eulogised Osama Bin Laden and Mohammed Atta, one of attackers. The track contained the lyrics: "I worship the prophet / The Great Mohammed / Omar Atta / For his courage behind the wheel of the plane / Reminds me when I was dealin' the 'caine« (NME, 24 August 2002: 2). These lyrics were dropped before the track was released on the Diplomatic Immunity album. Meanwhile Michael Franti, of Spearhead, distinguished himself by speaking out against the war in Iraq (Campbell 2002), while Eminem merely made himself look stupid by appearing as Osama Bin Laden in his »Without Me « video.

More generally in a highly passionate review, Greil Marcus (2002) accused the American left of using $9 / 11$ as an excuse not to think. It is also 
worth noting that radical can be seen in musical as well as political terms. In the latter instance it is interesting to note that radical musical forms such as nu metal and rap were overwhelmingly absent from the musical mega-events which marked $9 / 11$, despite their popularity with younger audiences. Murray Forman comments that:

»This aesthetic exclusions - which can accurately be described as a structured absence, which correlates with mainstream radio's frequent sno punk, no junk « or sno rap, no crap < format statements - speaks to the relatively flaccid character of dominant mainstream tastes and reflects the middle-brow biases of the executive producers involved in the projects while reproducing the prevailing hegemony in highly significant ways« (Forman 2002: 19).

In the UK one of its more radical bands, Primal Scream, re-recorded a song known as »Bomb The Pentagon« under the new title of »Rise« (NME, 1 June 2002: 2). Other acts got pushed into being radical merely by wanting to comment on the situation. The Black Rebel Motorcycle Club »US Government « track was recorded and then the band came under record label pressure to omit it from their second album, Take Them On, On Your Own, following the attacks on the Dixie Chicks. However, guitarist Peter Hayes commented that:

"But the whole fucking point of art is to question what's going on! And that used to be respected, a gift for society. That's art's purpose, and artists have every right in the fucking world to do that. But somehow, now it's gotten to the point where even the fuckin' Dixie Chicks can't talk about it! So if that song opens up a conversation about what we're going through now, then I think that's a good thing « (Parker 2003).

Thus in a sense some artists were pushed into radicalism. But, as noted earlier, some former radicals found their work incorporated into mainstream such as the use of Pete Seeger's version of "This Land Is Your Land " on the God Bless America CD which also includes Mahalia Jackson singing »We Shall Overcome $«$. Thus at the same time as some forms of radical music was marginalised during attempts to come to terms with $9 / 11$, other forms which had previously been used to oppose the political status quo were now being used to shore it up.

\section{Conclusion}

What I hope to have done is to show that the musical responses which were made by musicians and others involved in the music industry post 9/11 are wrapped up in notions of what it is to be American. Initially this involved a 
denial that music was an appropriate response through to a realisation that music could play all its usual roles - comforter, interpreter and antagonist. The musical responses took longer to come to fruition and can be seen within broader trends of conservative and liberal patriotism and radicalism. If, as I argued, the events on 9/11 were an attack on the very idea of America, then musical responses were made in ways in which the idea of America was again contested. Historically a key part of what America has been about is a search for a particular vision of freedom. That vision was articulated in music after $9 / 11$, but it was also debated. After 9/11 music did not change, but the politics around it did and, as I hope I have shown, music made its own contribution to those changes.

\section{Bibliography}

American Civil Liberties Union (ACLU) (2002). Freedom Under Fire: Dissent in Post 9.11 America. New York: ACLU.

Attali, Jacques (1985). Noise. Manchester: Manchester University Press.

Anderson, Benedict (1991). Imagined Communities. London: Verso.

Beaumont, Mark (2001). »Can Music Ever be the Same Again. In: NME, 29 September, pp. 18-20.

Bright, Martin (2003). [Review of Steve Earle concert]. In: Observer, 6 April, p. 10.

Campbell, Duncan (2002). "9/11 Beat: Musicians Cash in on Anniversary. « In: Guardian, 3 August, Review Section, p. 14.

Campbell, Duncan (2003). "Saddam's Angels Fight on with Naked Desire." In: Guardian, 25 April, p. 1.

Cloonan, Martin (1996). Banned! Aldershot: Arena.

Cloonan, Martin (1997). "State of the Nation: Englishness, Pop and Politics in the Mid 1990s.«In: Popular Music and Society, 21:2, pp. 47-70.

Davidson, Ros (2002). »Outrage over >Offensive Taliban Lyrics. «In: Sunday Herald, 28 July, p. 18.

Ellison, Michael (2001). "Star Studded Tribute.«In: Guardian, 22 October, p. 7.

Forman, Murray (2002). "Soundtrack to a Crisis: Music, Context, Discourse." In: Television and New Media, 3:2, pp. 191-204.

Frith, Simon (1987). "Towards an Aesthetic of Popular Music.«In: Music and Society. Ed. by Richard Leppert and Susan McClary. Cambridge: Cambridge University Press, pp. 133-149.

Frith, Simon (1996) »Music and Identity.«In: Questions of Cultural Identity. Ed. by Stuart Hall and Paul du Gay. London: Sage. pp. 108-127.

Garside, Juliette (2001). »McCartney Sings for Freedom at New York's Own Live Aid.« In: Sunday Herald, 21 October, p. 3.

Garofalo, Reebee (Ed.) (1992). Rockin' The Boat. Boston: South End Press.

Harris, John (2002) »My Country is Sleep Walking. « [Interview with Steve Earle]. In: Guardian, 23 September, part two, pp. 10-11.

Helmore, Ed (2001). »Celebrity Aid.«In: Observer, 23 September, p. 2. 
Kettle, Martin (2001). »The Witch-Hunt. «In: Guardian, 15 December, Saturday Review, p. 5.

Long, April (2001). "The Boys are Back in Town« [Review of New Yorkers Against Violence]. In: NME, 10 November, p. 36.

Lynskey, Dorian (2002). »Draft Me!« In: Guardian, 22 January, part two, pp. 12-13.

Marcus, Greil (2002). »Nothing New under the Sun.« In: First of the Month, 4:1, pp. 9-12.

Martin, Linda and Segrave, Kerry (1988). Anti-Rock. New York: De Capo.

Negus, Keith (1996). Popular Music in Theory. Cambridge: Polity.

Nuzum, Eric (2001). Parental Advisory: Music Censorship in America. New York: Perennial.

Nuzum, Eric (2002). „Crash into Me, Baby: America's Implicit Music Censorship in the Wake of September 11th. "Paper presented at Second World Conference on Music and Censorship, Copenhagen, 29 September [http://ericnuzum.com/ banned/articles/paper_wcmc.html (accessed 2004, 6 May)].

Parker, Lyndsey (2003). »Up to Their Necks in It.« In: NME, 14 June, p. 20.

Petridis, Alexis (2001). »Pop. «In: Guardian, 29 September, Saturday Review, p. 6.

Petridis, Alexis (2002). »Darkness on the Edge of Town. « In: Guardian, 26 July, Friday Review, p. 11.

Robbins, Tim (2003). "Our Voices are Lost in the Tide of Intolerance Sweeping America.« In: Observer, 20 April, p. 15.

Ross, Peter (2003). "Shinier Happier People.«In: Sunday Herald, 15 June, Seven Days, pp. 4-5.

Sutherland, John (2002). "A Redneck Country Singer is Tops with Guys in Uniform. No Wonder Dubya Invited Him to the White House.« In: Guardian, 26 August, part two, p. 7.

Wilson, Sue (2003). »Iraq has Nothing to Do with 9/11 « [Interview with Steve Earle]. In: Sunday Herald, 30 March, Review section, p. 11.

Williamson, Nigel (2003). »Free the Dixie Three.«In: Guardian, 22 August, Friday Review, pp. 7-8 [http://www.guardian.co.uk/arts/fridayreview/story/0,12102, 1026475,00.html (accessed 2004, 6 May)].

Zalot, Michael C. (2002). »Turning away from the Television Tape Loop: Characterising Some Local Rock, Pop and Country Music Radio Stations Responses to the September 11, 2002, Terrorist Attacks. « In: New Jersey Journal of Communication, 10:1 (Spring), pp. 26-48.

\begin{abstract}
This article poses the question: What would a suitable American popular music response to the events of $9 / 11$ sound like? In order to do this, first the initial musical responses to $9 / 11$ are charted, before more longer term responses are characterised as being from conservative patriotic, liberal and radical angles. Throughout the article it is argued that musical responses were both inevitable and inevitably controversial. It is suggested that examination of the musical responses to $9 / 11$, can give insights into both notions of American identity and the power of popular music in articulating them.
\end{abstract}

